\title{
The Effect Of Working Capital Management On Firm's Profitability: Empirical Evidence From An Emerging Market
}

Melita Stephanou Charitou, University of Nicosia, Cyprus

Maria Elfani, University of Nicosia, Cyprus

Petros Lois, University of Nicosia, Cyprus

\begin{abstract}
$^{1}$
In this study, we empirically investigate the effect of working capital management on firm 's financial performance in an emerging market. We hypothesize that working capital management leads to improved profitability. Our data set consists of firms listed in the Cyprus Stock Exchange for the period 1998-2007. Using multivariate regression analysis, our results support our hypothesis. Specifically, results indicate that the cash conversion cycle and all its major components; namely, days in inventory, days sales outstanding and creditors payment period - are associated with the firm's profitability. The results of this study should be of great importance to managers and major stakeholders, such as investors, creditors, and financial analysts, especially after the recent global financial crisis and the latest collapses of giant organizations worldwide.
\end{abstract}

Keywords: Capital Markets; Working Capital Management; Empirical

\section{INTRODUCTION}

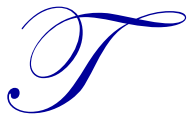

he recent global financial crisis and the collapses of colossal organizations such as General Motors, Lehman Brothers, Bear Stearns, among others, brought to the forefront of capital markets research the importance of management of organizational resources, and especially working capital management. Working capital is described as the capital available to meet the day-to-day operations, and depending on the industry, it could be a relatively high percentage of the total assets of the organization. Executives have been emphasizing the efficient utilization of firm's resources since there is a belief that it has an effect on the firm's financial performance, but there has been little empirical evidence on this specific issue (Ricci and N. DiVito, 1998; Garcia-Teruel \& Martinez Sonano, 2007; Hill et al., 2010).

Efficient utilization of the firm's resources, as it relates to working capital management, means that executives should find effective and efficient ways to deal with the cash available for the day-to-day operations in order to achieve the optimum impact. Good working capital management leads to increased cash flows, and thus leads to lesser need on external financing; therefore, the probability of default for the firm is reduced. A key factor in the working capital management is the cash conversion cycle (Deloof, 2003). Cash conversion cycle is defined as the time lag between the purchasing of raw materials or rendering of services and the collection of cash from the sale of goods or services rendered. The longer the lag, the greater the investment in working capital, and thus the financing needs of the firm will be greater. Interest expense will be also higher, which leads to higher default risk and lower profitability.

In this study, we empirically investigate the effect of working capital management on the firm's financial performance in an emerging market. We hypothesize that working capital management leads to improved profitability. Our data set consists of firms listed on the Cyprus Stock Exchange for the 10-year period 1998-2007.

\footnotetext{
${ }^{1}$ This manuscript was original published in the Journal of Business \& Economics Research 8(12), 63-68. Due to high download rates this manuscript has been reprinted. 
Using multivariate regression analysis, our results support our hypothesis. Specifically, results indicate that the cash conversion cycle and all its major components; namely, days in inventory, days sales outstanding and creditors payment period, are associated with firm's profitability.

The remainder of the study is organized as follows: Section 2 provides background and hypotheses development. In Section 3, we discuss the research design. Empirical results are discussed in section 4 and conclusions are presented in the last section.

\section{LITERATURE REVIEW}

Prior studies reported that working capital management may have an important effect on the firm's profitability. Shin and Soenen (1998), Lazaridis and Tryfonidis (2006), Raheman and Nasr (2007), among others, measured working capital with cash conversion cycle, which consists of stockholding period, debtors' collection period and creditors' payment period. These researchers supported that greater investment in working capital (the longer cash conversion cycle) leads to reduction in the firm's profitability (Banos-Caballero et al, 2010, and Nazir \& Afza, 2003, 2009).

Deloof (2003) used a sample of Belgian firms and found that firms can increase their profitability by reducing the debtor's collection period and the days-in-inventory period. He also found that less profitable firms wait longer to pay their bills. Wang (2002) used a sample of Japanese and Taiwanese firms and found that a shorter cash conversion cycle would lead to a better firm's operating performance. Teruel and Solano (2007) took samples of small to medium-sized Spanish firms for the 1996-2002 period and found that the firms can create value by reducing the days-in-inventory period and the debtor's collection period, thus leading to the reduction in the cash conversion cycle.

On the other hand, though, other researchers support that investing more in cash conversion cycle (conservative policy) may lead to increased profitability since maintaining high inventory levels is expected to increase sales, reduce supply costs, reduce cost of possible interruption in production and protect against price fluctuations (Blinder and Maccini, 1991). A higher debtors' collection period may also strengthen the relationship with customers and hence may lead to an increase in sales revenue (Ng et al, 1999). Deloof (2003) showed that a relatively huge amount of firms' assets are reserved for working capital. Summers and Wilson (2000) also stated that more than $80 \%$ of the daily business transactions in the UK corporate sector is on credit terms.

As it can be seen from the aforementioned empirical evidence, there are inconclusive and inconsistent results with regard to the role of working capital management on firms' financial performance. This is due to the fact that researchers used either the conversion cycle as it relates to the firm's profitability or they examined only part of the components of the conversion cycle.

We extend prior studies in the following respects. First, we examine both the conversion cycle and all its components. Second, we use a relatively large time period to investigate this issue, which is a 10 -year period. Third, we extend prior research by examining an emerging European Union country; namely, Cyprus. To the best of our knowledge, no one has examined this issue using data from an emerging European Union country. It is important to examine this issue for this emerging country since the Cyprus Stock Exchange (CSE) is considered one of the most volatile exchanges worldwide. During the 1999 stock market boom, the CSE gained more than $800 \%$ in less than one year and then it dropped more than $90 \%$ over a short period of time (less than two years). During the recent global financial crisis, the CSE stock market index dropped substantially, again suffering from one of the largest drops worldwide. These huge fluctuations in the capital markets are due, to some extent, to changes in the firm's profitability, which is affected by the firm's working capital management. We expect that if executives of CSE firms pay more attention to the efficient utilization of resources; eg., working capital management, these firms may have a stronger and smoother stream of earnings which may lead to value creation and, at the same time, to smoother changes in stock prices and thus mitigate the large volatility in stock prices. 


\section{RESEARCH METHODOLOGY}

\subsection{Data set and Measurement of Variables}

Our data set consists of all industrial firms listed in the Cyprus Stock Exchange that had financial data available for the period 1998-2007. Financial institutions and financial firms were excluded from the sample due the distinct nature of their operations. In total, 43 firms met all our criteria and were included in the sample. All data were hand collected from the annual reports of each firm.

As it has already been discussed, the cash conversion cycle is the measure of working capital management, where it is measured as follows:

$$
\text { Cash Conversion Cycle }=\text { Stockholding Period }+ \text { Debtors Collection Period }- \text { Creditors Payment Period }
$$

The components of cash conversion cycle are measured as follows:

$$
\begin{aligned}
& \text { Stockholding Period }=\text { Stock } / \text { Cost of Sales } * 365 \\
& \text { Debtors Collection Period }=\text { Stock } / \text { Sales } * 365 \\
& \text { Creditors Payment Period }=\text { Creditors } / \text { Cost of Sales } * 365
\end{aligned}
$$

To analyze the effect of working capital management on profitability, we operationalize profitability as Return on Assets (ROA). ROA is defined as:

$$
\text { Return on Assets }=\text { Operating Profit/Total Asset }
$$

The control independent variables are the natural logarithm of sales, sales growth and debt ratio which are calculated as follows:

$$
\begin{aligned}
& \text { Natural Logarithm of Sales }=\operatorname{Ln}(\text { Sales }) \\
& \text { Sales Growth }=\left(\text { Sales }_{t}-\text { Sales }_{\mathrm{t}-1}\right) / \text { Sales }_{\mathrm{t}-1} \\
& \text { Debt Ratio = Total Liabilities } / \text { Total Asset }
\end{aligned}
$$

\subsection{Empirical Models}

In order to test our proposition, we regress the cash conversion cycle and its components on firms' profitability (Deloof, 2003, and Teruel \& Solano, 2007). The following models will be tested:

$$
\begin{aligned}
& \text { ROA }_{\text {it }}=\beta_{0}+\beta_{1} \text { STOCK }_{\text {it }}+\beta_{2} \text { LNSALES }_{i t}+\beta_{3} \text { SGROW }_{\text {it }}+\beta_{4} \text { DEBT }_{\text {it }}+e_{i t} \\
& \text { ROA }_{i t}=\beta_{0}+\beta_{1} \text { DEBTOR }_{i t}+\beta_{2} \text { LNSALES }_{i t}+\beta_{3} \text { SGROW }_{\text {it }}+\beta_{4} \text { DEBT }_{\text {it }}+e_{i t} \\
& \text { ROA }_{i t}=\beta_{0}+\beta_{1} \text { CREDITOR }_{i t}+\beta_{2} \text { LNSALES }_{i t}+\beta_{3} \text { SGROW }_{\text {it }}+\beta_{4} \text { DEBT }_{\text {it }}+e_{i t} \\
& \mathrm{ROA}_{\mathrm{it}}=\beta_{0}+\beta_{1} \mathrm{CCC}_{\mathrm{it}}+\beta_{2} \mathrm{LNSALES}_{\mathrm{it}}+\beta_{3} \mathrm{SGROW}_{\mathrm{it}}+\beta_{4} \mathrm{DEBT}_{\mathrm{it}}+\mathrm{e}_{\mathrm{it}}
\end{aligned}
$$

where:

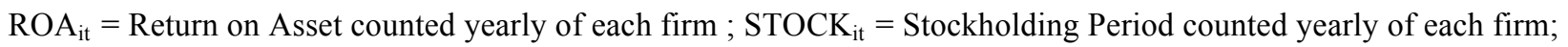
DEBTOR $_{\text {it }}=$ Debtors Collection Period counted yearly of each firm; CREDITOR $_{\text {it }}=$ Creditors' Payment Period counted yearly of each firm; $\mathrm{CCC}_{\mathrm{it}}=$ Cash Conversion Cycle counted yearly of each firm; LNSALES $_{\mathrm{it}}=$ Natural Logarithm of Sales counted yearly of each firm; $\mathrm{SGROW}_{\mathrm{it}}=$ Sales Growth counted yearly of each firm; $\mathrm{DEBT}_{\mathrm{it}}=$ Debt Ratio counted yearly of each firm. 
$\mathrm{i}=1, \ldots . \mathrm{n}$, where $\mathrm{n}$ is the total number of firms; $\mathrm{n}=43$

$\mathrm{e}_{\mathrm{it}}=$ estimate of yearly residual for each firm

\section{EMPIRICAL RESULTS}

Table 1 presents descriptive statistics for all variables used in the present study for all 43 firms over the 10-year period. In total, 430 firm year observations were used. The average value of return on assets is $5 \%$. The maximum value of ROA is $49 \%$, while the minimum is $-30 \%$. The average days in inventory (STOCK) is 103 days. The mean days sales outstanding (DEBTOR) is 248 days and the number of days it takes to pay their suppliers (CREDITOR) is 210 days. The yearly average sales is $£ 23$ million. The average annual growth in sales is $28 \%$ and the average debt ratio is $46 \%$.

Table 1. Descriptive Statistics Results for All Variables Tested for All Firms over the 10-year Period

\begin{tabular}{l|c|c|c|r}
\hline \multicolumn{1}{c|}{ Variable } & $\mathbf{N}$ & Minimum & Maximum & Mean \\
\hline ROA & 430 & -0.30 & 0.49 & 0.05 \\
\hline STOCK & 430 & 0 & 729.00 & 103.00 \\
\hline DEBTOR & 430 & 0 & 529.00 & 248.00 \\
\hline CREDITOR & 430 & 0 & 343.00 & 210.00 \\
\hline CCC & 430 & -278 & 748.00 & 214.00 \\
\hline SALES & 430 & 1 & 25.50 & 23.32 \\
\hline LNSALES & 430 & 0 & 19.36 & 15.95 \\
\hline SGROW & 430 & -1 & 19.38 & 0.28 \\
\hline DEBT & 430 & 0.025 & 1.17 & 0.46 \\
\hline
\end{tabular}

where

$\mathrm{ROA}_{\mathrm{it}}=$ Return on Asset counted yearly of each firm ; STOCK $\mathrm{it}=$ Stockholding Period counted yearly of each firm;

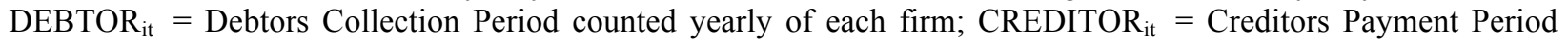
counted yearly of each firm; $\mathrm{CCC}_{\mathrm{it}}=$ Cash Conversion Cycle counted yearly of each firm; LNSALES $_{\mathrm{it}}=\mathrm{Natural}$

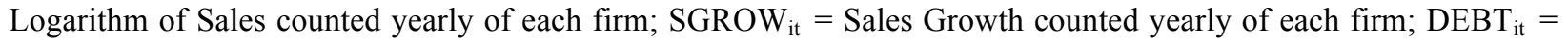
Debt Ratio counted yearly of each firm.

Results in Table 2 show Pearson's correlation analysis among all variables under investigation. As hypothesized, profitability has an inverse relationship with the cash conversion cycle and the components of this cycle; namely, days in inventory, days in receivables and days payables. These results indicate that the firm's financial health is inversely related to the components of the cash conversion cycle. The relationship between profitability and the control variables; namely, sales growth, Debt Ratio and the level of debt, is also consistent with our expectations.

Table 2. Pearson Correlations for All Variables Tested for All Firms over the 10-year Period

\begin{tabular}{|c|c|c|c|c|c|c|c|c|c|}
\hline & ROA & STOCK & DEBTOR & CREDITOR & $\mathrm{CCC}$ & SALES & LNSALES & SGROW & DEBT \\
\hline ROA & 1 & -0.048 & -0.053 & -0.051 & -0.048 & $-.172^{* *}$ & -0.077 & 0.074 & $-.167^{* *}$ \\
\hline STOCK & & 1 & $.998^{* *}$ & $.993^{* *}$ & $1.000^{* *}$ & -0.036 & $-.145^{* *}$ & -0.026 & $-.096^{*}$ \\
\hline DEBTOR & & & 1 & $.993^{* *}$ & $.998^{* *}$ & -0.043 & $-.147^{* *}$ & -0.027 & $-.099^{*}$ \\
\hline CREDITOR & & & & 1 & $.993^{* *}$ & -0.042 & $-.138^{* *}$ & -0.026 & -0.074 \\
\hline $\mathrm{CCC}$ & & & & & 1 & -0.036 & $-.145^{* *}$ & -0.026 & $-.097^{*}$ \\
\hline SALES & & & & & & 1 & $.501^{* *}$ & -0.045 & $.290^{* *}$ \\
\hline LNSALES & & & & & & & 1 & 0.001 & $.143^{* *}$ \\
\hline SGROW & & & & & & & & 1 & -0.072 \\
\hline DEBT & & & & & & & & & 1 \\
\hline
\end{tabular}

$* *, *$ : statistically significant at the $1 \%, 5 \%$, respectively

where

$\mathrm{ROA}_{\mathrm{it}}=$ Return on Asset counted yearly of each firm ; STOCK $\mathrm{St}_{\mathrm{it}}=$ Stockholding Period counted yearly of each firm; DEBTOR $_{i t}=$ Debtors Collection Period counted yearly of each firm; CREDITOR ${ }_{i t}=$ Creditors Payment Period 
counted yearly of each firm; $\mathrm{CCC}_{\mathrm{it}}=$ Cash Conversion Cycle counted yearly of each firm; LNSALES $_{\mathrm{it}}=$ Natural Logarithm of Sales counted yearly of each firm; $\mathrm{SGROW}_{\mathrm{it}}=$ Sales Growth counted yearly of each firm; $\mathrm{DEBT}_{\mathrm{it}}=$ Debt Ratio counted yearly of each firm.

In order to test our hypothesis, we employed the multivariate regression analysis. Specifically, we hypothesized that the components of the cash conversion cycle affect firms' profitability. Results in Table 3 provide results for the models tested in the present study. Model 1 tests the relationship between days in inventory (STOCK) and three control variables with profitability. The model is statistically significant, as it is indicated by the F-value. As expected, results show that days in inventory (STOCK) is inversely related to profitability. The sales growth has a positive coefficient with the ROA, meaning that growth leads to increase in profitability. Also, as expected, high leveraged firms (DEBT) are less profitable due to the fact that these firms have higher default risk.

Model 2 regresses ROA against days sales outstanding (DEBTOR) and the three control variables. As expected, the DEBTOR variable is negatively related to profitability and leverage again is inversely related to profitability. This model is statistically significant, as indicated by the $\mathrm{F}$ test. The model's $\mathrm{R}^{2}$ is $4.1 \%$.

As far as Model 3 is concerned, it regresses ROA against days payable (CREDITOR) and the three control variables. The model is statistically significant, as it is indicated by the F-value. As expected, results show that days payable (CREDITOR) is inversely related to profitability, meaning that less profitable firms take longer to repay their obligations. Again, as expected, high leveraged firms (DEBT) are less profitable due to the fact that these firms have higher default risk. These results are consistent with Deloof's (2003) findings.

Regarding Model 4, it regresses the cash conversion cycle and the control variables against ROA. As expected, the cash conversion cycle is inversely related to profitability. Again, as expected, the DEBTOR variable is negatively related to profitability and leverage again is inversely related to profitability. This model is statistically significant, as indicated by the $\mathrm{F}$ test. The model's $\mathrm{R}^{2}$ is $4 \%$.

Table 3. Multivariate Regression Analysis Models (For All Years Tested for All Firms)

\begin{tabular}{|c|c|c|c|c|c|c|c|c|}
\hline \multirow[b]{2}{*}{ Variable } & \multicolumn{2}{|c|}{ Model 1} & \multicolumn{2}{|c|}{ Model 2} & \multicolumn{2}{|c|}{ Model 3} & \multicolumn{2}{|c|}{ Model 4} \\
\hline & Coefficient & p-value & Coefficient & p-value & Coefficient & p-value & Coefficient & p-value \\
\hline Constant & $* * * 4.06$ & 0 & $* * * 4.09$ & 0 & $* * * 4.1$ & 0 & $* * * 4.1$ & 0 \\
\hline Stock & -1.48 & 0.14 & & & & & & \\
\hline Insales & -1.33 & 0.18 & -1.35 & 0.18 & -1.33 & 0.19 & -1.34 & 0.18 \\
\hline SGROW & 1.27 & 0.2 & 1.27 & 0.21 & 1.28 & 0.2 & 1.27 & 0.2 \\
\hline DEBT & $* * *-3.33$ & 0 & $* * *-3.34$ & 0 & $* * *-3.3$ & 0 & $* * *-3.3$ & 0 \\
\hline DEBTOR & & & -1.6 & 0.11 & & & & \\
\hline Creditor & & & & & -1.46 & 0.35 & & \\
\hline $\mathrm{CCC}$ & & & & & & & -1.49 & 0.1 \\
\hline F-value & $* * * 4.4$ & 0 & $* * * 4.5$ & 0 & $* * * 4.4$ & 0 & $* * * 4.4$ & 0 \\
\hline R-square & $4 \%$ & & $4.1 \%$ & & $4 \%$ & & $4 \%$ & \\
\hline
\end{tabular}

where

$\mathrm{ROA}_{\mathrm{it}}=$ Return on Asset counted yearly of each firm ; $\mathrm{STOCK}_{\mathrm{it}}=$ Stockholding Period counted yearly of each firm; DEBTOR $_{i t}=$ Debtors Collection Period counted yearly of each firm; CREDITOR ${ }_{i t}=$ Creditors Payment Period counted yearly of each firm; $\mathrm{CCC}_{\mathrm{it}}=$ Cash Conversion Cycle counted yearly of each firm; LNSALES $_{\text {it }}=$ Natural

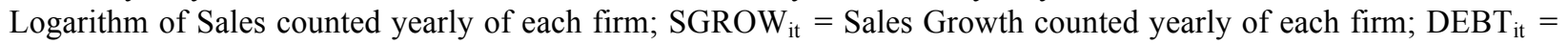
Debt Ratio counted yearly of each firm.

In summary, the aforementioned results confirm our expectations; i.e., that the components of the cash conversion cycle, if managed efficiently, add value to the firm since they increase firm's profitability. 


\section{CONCLUSIONS}

The recent global financial crisis brought to the forefront of research the efficient utilization of firm's resources. Better utilization of resources leads to value creation. In this study, we empirically investigated the effect of working capital management on firm's financial performance in an emerging market. We hypothesized that working capital management leads to improved profitability. Using a sample of 43 firms listed on the Cyprus Stock Exchange for the period 1998-2007, our multivariate regression analysis results indicated that the cash conversion cycle and all its major components; namely, days in inventory, days sales outstanding and creditors payment period, are associated with firm's profitability.

In the recent turbulent times and global financial crisis, the results of this study should be of great importance to executives and major stakeholders, such as investors, financial analysts, and bankers. Efficient utilization of the firm's resources leads to increased profitability and reduces volatility, which leads to the reduction in default risk and thus improves the firm's value.

\section{AUTHOR INFORMATION}

Dr Petros Lois holds an MSc degree in Accounting from De Montfort University (UK), and a PhD degree in Marine Technology from Liverpool John Moores University (UK). He is a Certified Management Accountant (ICMA) and he holds the Chair of PwC in Business Research at the University of Nicosia. He is currently an Associate Professor and the Director of Academic Affairs Department at the University of Nicosia, Cyprus. He has also served as the Head of the Accounting Department and the coordinator of the two professional qualifications namely CIA (Certified Internal Auditors, USA) and CFA (Chartered Financial Analysts, USA). He is a member of the Institute of Certified Management Accountants of Australia (ICMA), the Institute of Marine Engineers, Science and Technology (IMarEST, UK), and the National Book-keepers Association (NBA, USA). He is a member of the Board of Directors of the Cyprus Port Authority (CPA). His research interests include accounting, working capital management, finance, and shipping (maritime). His research work has been published in international conference proceedings, books and journals.

Dr. Melita Stephanou Charitou is an Associate Professor of Finance and Accounting. She holds a BSc degree in Accounting, MSc in Finance and $\mathrm{PhD}$ in Finance and Accounting. Her research interests are: financial analysis, capital market, international financial management and credit analysis. She has published in several international refereed journals, among those, Accounting and Finance, International Journal of Business and Social Research (best paper award), Investment Management and Financial Innovations, Journal of Business and Economic Research, Journal of Economics and International Finances. She has taught in both undergraduate and graduate (MBA) programs. Teaching interests include: Financial Management, Corporate Finance, Financial Accounting and Managerial Accounting.

\section{REFERENCES}

Banos-Caballero S, P. Garcia-Teruel and P. Martinez-Solano (2010), Accounting and Finance, Vol 50, pp. 511-527, September.

Blinder, A.S. and Maccini, L.J. (1991), “The Resurgence of Inventory Research: What Have We Learned?", Journal of Economic Survey, Vol. 5, pp. 291-328.

Cyprus Stock Exchange (2009), CSE Bulletin, May 2009 Edition, Issue 148.

Deloof, M. (2003), “Does Working Capital Management Affect Profitability of Belgian Firms?”, Journal of Business, Finance and Accounting, Vol. 30 No. 3 \& 4, pp. 573-587.

Garcia-Teruel P., P Martinez Sonano, (2007) Effects of Working Capital Management on SME Profitability, International Journal of Managerial Finance, Vol. 3, pp. 164-177.

Gitman, L.J. (1974), "Estimating Corporate Liquidity Requirements: A Simplified Approach”, The Financial Review, Vol. 9, pp. 79-88.

Hill M, G. Kelly and M. Highfield (2010), Net Operating Working Capital Behavior: A first Look, Financial Management (forthcoming)

Lazaridis, I. and Tryfonidis, D. (2006), “The Relationship between Working Capital Management and Profitability of Listed Companies in the Athens Stock Exchange", Journal of Financial Management and Analysis, Vol. 19 No.1, pp. 26-35.

Nazir M and T Afza, (2003), The focus of Working Capital Management in UK Small Firms, Managerial Accounting Research, Vol. 14, June. 
Nazir M and T Afza, (2009), Impact of Aggressive Working Capital Management Policy on Firm's profitability, The IUP Journal of Applied Finance, Vol. 15, Aug.

Ng, C.K., Smith, J.K. and Smith, R.L. (1999), "Evidence on the Determinants of Credit Terms Used in Interfirm Trade", Journal of Finance, Vol. 54, pp. 1109-1129.

Raheman, A. and Nasr, M. (2007), "Working Capital Management and Profitability - Case of Pakistani Firms", International Review of Business Research Papers, Vol. 3 No.1, pp. 279-300.

Ricci C., and N. DiVito (1998), International Working Capital Practices, European Financial Management.

Shin, H.H. and Soenen, L. (1998), "Efficiency of Working Capital and Corporate Profitability", Financial Practice and Education, Vol. 8, pp. 37-45.

Summers, B. and Wilson, N. (2000), "Trade Credit Management and the Decision to Use Factoring: An Empirical Study", Journal of Business, Finance and Accounting, Vol. 27 No.1 \& 2, pp. 37-68.

Teruel, P.J.G. and Solano, P.M. (2007), "Effects of Working Capital Management on SME Profitability”, International Journal of Managerial Finance, Vol. 3 No.2, pp. 164-177.

Wang, Y.J. (2002), "Liquidity Management, Operating Performance, and Corporate Value: Evidence from Japan and Taiwan", Journal of Multinational Financial Management, Vol. 12, pp. 159-169. 
NOTES 